\title{
Arte con mayúsculas y minúsculas
}

En el cine más que en ningún lenguaje artístico es visible la existencia de dos campos excluyentes que coexisten con abierta hostilidad. Me refiero al cine de masas, comercial, de consumo para el gran público; y al cine de arte, de entendidos, que lleva una existencia relativamente marginal, al amparo de los subsidios de los ministerios de cultura, de pequeñas salas de entendidos y de cinéfilos. En nuestro país, el consumo del primero sobre el segundo es claramente predominante. El segundo circula gracias al esfuerzo de algunas embajadas, de cine-clubs o de algunos errores de las distribuidoras nacionales. Esta dicotomía del cine se enmarca dentro de otra mucho más amplia en el terreno artístico, entre la cultura de masas y la alta cultura. Ésta última usualmente se arroga la exclusividad del término cultura y lo escribe con mayúsculas. Estamos, pues, hasta dos campos, organizados de distinta forma y que utilizan distintos parámetros para atribuir valor a sus productos.

En la cultura de masas priva fundamentalmente el criterio comercial. Es İa cultura transformada en mercancía. La aceptación del público traducida en dinero contante y sonante para las empresas productoras es el principal criterio de validez. Un película, una canción, un libro es bueno si se vende. En el segundo caso, en el del Arte con mayúsculas, existen fundamentalmente criterios de excelencia formal y, en menor grado, de relevancia temática. Dichos criterios pueden variar $\mathrm{y}$, de hecho, han variado a lo largo del tiempo. Pero lo que permanece constante es que son criterios manejados fundamentalmente por entendidos, quienes sancionan el 'valor estético' independientemente del grado de aceptación o popularidad entre el público.
Tomando una perspectiva histórica muy amplia vemos que ambas manifestaciones son típicas de la era moderna. Son producto de una cultura mediada por instituciones y expertos y no de la cultura cara a cara, de transmisión directa, propia de las sociedades menos complejas. Lo que pasa es que al complejizarse la sociedad y al especializarse sus funciones, también se complejiza y diversifica la producción de efectos estéticos, es decir, de 'arte'. Simplificando mucho el proceso histórico, diremos que de esta división resultó un arte que satisfacía las necesidades de entretenimiento, de diversión y un arte más preocupado en 'elevar' la sensibilidad y la cultura del público.

En la sociedad contemporánea, el arte de masas es ante todo una gran industria, un negocio. Es, por ejemplo, una de las industrias líderes de Estados Unidos. Uno de los pocos terrenos en que no ha sido desplazado o amenazado por sus competidores europeos o asiáticos, en esta era global. Con toda la universalización del espíritu pragmático y utilitario que hemos visto en los últimos siglos, no se ha erradicado la necesidad de la gente de dar vuelo a la imaginación y a la fantasía, de liberarse de las garras de la cotidianidad gris y anodina (aburrida, en algunos casos; infernal, en muchos más) que el progreso moderno ha creado. El arte de entretenimiento provee así soluciones imaginarias, escapes de la realidad, bálsamos para que la maquinaria de la sociedad moderna pueda seguir funcionando con renovadas energías.

Ésta es una lógica que camina por sí sola, que no obedece al diseño de genio maligno alguno. El público busca esparcimiento, no reflexión. $\mathrm{La}$ in- 
dustria del entretenimiento, por otro lado, está dispuesta a ofrecer aquello que tenga un rendimiento económico asegurado, es decir, que no se enfrente al rechazo del público o que despierte reparos en instancias de poder que puedan influir en la respuesta positiva de dicho público. Aunque, en honor a la verdad, esto tiende a cambiar. El público consumidor de cultura de la modernidad tardía es altamente heterogéneo y selectivo.

La función que le corresponde al arte con mayúsculas en el mundo contemporáneo es mucho menos clara y continúa siendo objeto de acalorados debates. Sus defensores y propulsores sostienen que desempeña una función crítica. El verdadero artista aprehende estéticamente lo fundamental de la realidad y lo plasma en su creación. El receptor al entrar en diálago con la obra artística no sólo accede a una comprensión mayor de su mundo, sino que desarrolla las facultades necesarias para enfrentarse a la vida de manera distinta, renovada, más auténtica. Ésta es la línea que parte de los primeros románticos y culmina en la filosofía estética de la escuela de Frankfurt, especialmente en los escritos de T. W. Adorno. Sin embargo, en la actualidad, existe toda una línea de reflexión culturalista que denuncia el Arte. Pensemos en Pierre Bourdieu y su estudio "La distinción" para una crítica social del gusto y toda una pléyade de críticos culturales anglosajones, pos y ex marxistas. Según muchos de estos autores, el arte se ha transformado menos en una actividad potenciadora del espíritu crítico que en una de las más importantes fuentes de distinción social. Importa menos el valor intrínseco de la obra que el prestigio que deriva de asociarse con ella. En este sentido, acaso veamos películas de Kurozawa no tanto porque amplíe mis horizontes de realidad cuanto porque incrementa mi prestigio ante otros por aparecer como degustador de "buen cine".

Sin entrar a fondo en resolver este problema, conviene resaltar que cada esfera de producción artística emplea lenguajes distintos. $\mathrm{O}$ mejor dicho, tiene actitudes completamente distintas hacia el lenguaje. Tradicionalmente se ha dicho que la cultura de masas usa un lenguaje degradado, fácil, iterativo, de constante recurso a los estereotipos y lugares comunes. El verdadero arte, en cambio, es una permanente búsqueda de la novedad expresiva y, sobre todo, de la perfecta articulación de forma y contenido. Distanciándonos temporalmente de

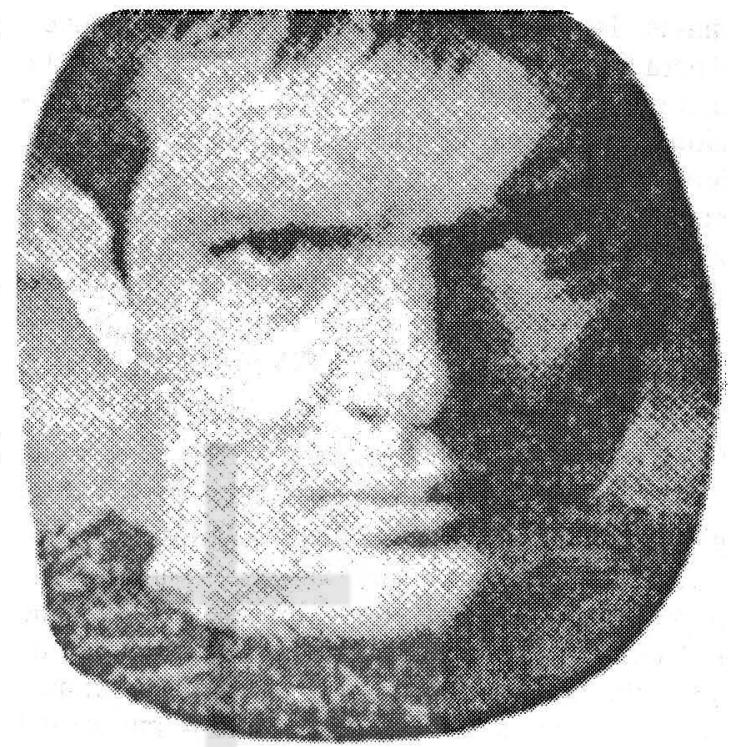

las cargas valorativas de estas definiciones, sí podemos constatar que, ya que los efectos que persigue cada una de las artes son distintos, su tratamiento del lenguaje debe variar en consecuencia.

El entretenimiento busca la empatía inmediata con el lector. La inmersión del receptor en el mundo fantástico que el lenguaje evoca. Es evidente que el arte popular 'transparentará' el lenguaje. Es decir, hará como si el lector estuviera en un mundo real y no en un mundo ficcional evocado por el lenguaje. Asimismo, el recurso a los clichés y a las fórmulas fácilmente reconocibles es un requisito para lograr la empatía de una audiencia heterogénea. El gran arte, por su parte, evitará deliberadamente las identificaciones fáciles y buscará, a través de recursos formales, mantener una actitud vigilante y alerta del receptor. Si eventualmente recurre a los géneros y convenciones del arte popular, lo hará paródicamente, es decir, con una intención distinta de la original: hacernos caer en la cuenta sobre los mecanismos que el arte de masas usualmente esconde.

Hemos visto, pues, que el arte de masas y el gran arte son diferentes. No necesariamente porque uno sea mejor que el otro, sino porque cumplen funciones distintas y establecen distintas relaciones con el receptor y el lenguaje. Esto no quiere decir, pues, que el arte popular sea inherentemente malo ni el gran arte bueno. Tampoco implica lo opuesto, como quisieran algunos. Hay logros en la alta cultura como los hay en la cultura de 
masas. También hay mediocridades y aberraciones. Ahora bien, si el arte culto, por lo general, contiene una mayor potencia crítica, tiene una gran limitación con respecto al arte masivo. En el mundo de hoy, el arte culto ha perdido la capacidad de generar mitos; de afectar el imaginario de grandes conglomerados humanos. Los referentes simbólicos de hoy en día son Rambo y Madonna y no Szymborska o Ligeti. De allí que, por mucho que nos sintamos inclinados, no podemos descalificar simplemente estas manifestaciones recurriendo a argumentos esteticistas.

El mundo contemporáneo con la creciente globalización y ubicuidad de los medios de comunicación electrónica le ha permitido ganar un terreno considerable al arte de masas. Terreno que se ha ganado a expensas de la alta cultura como de las culturas populares tradicionales, hoy en franco proceso de extinción. ¿Estamos ante la muerte del
Arte como lo hemos conocido hasta ahora? Es una pregunta difícil de responder. Siguen existiendo grandes artistas, grandes nombres, que hacen uso activo de los espacios creados por la cultura de masas, o remedan sus géneros. En Latinoamérica tenemos los ejemplos claros de un Manuel Puig o un Guillermo Cabrera Infante. La cultura de masas desempeña una función central en la transculturación de contingentes inmensos de población, hasta hace poco marginada de la modernidad. La realidad cultural contemporánea, la masificación del arte, plantean grandes interrogantes. El lector crítico de la cultura no puede pasar por alto ese llamado, debe afrontar la cultura en sus distintas manifestaciones y no encerrarse en una torre de marfil para seguir pretendiendo que el mundo sigue funcionando como en centurias pasadas.

\section{Ricardo Roque Baldovinos}

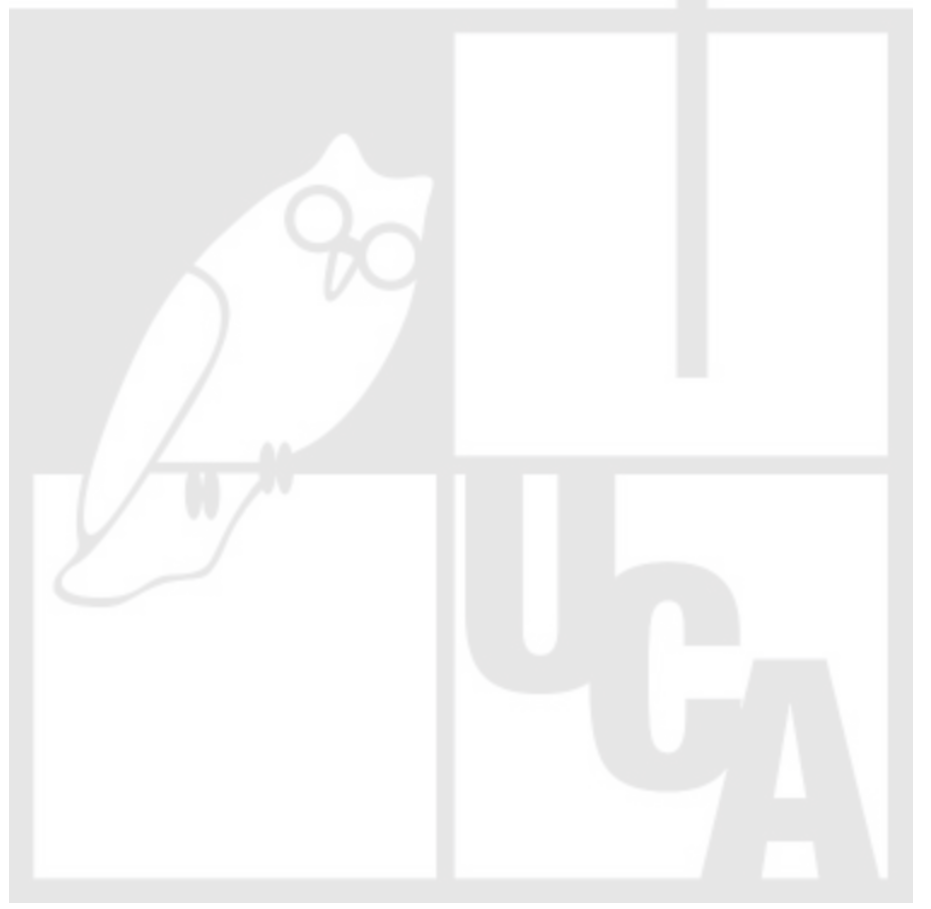

